\title{
TEMPORAL CHANGES IN RADIOCARBON RESERVOIR AGE IN THE DEAD SEA- LAKE LISAN SYSTEM
}

\author{
Mordechai Stein ${ }^{1} \cdot$ Claudia Migowski $^{2} \cdot$ Revital Bookman $^{3} \cdot$ Boaz Lazar $^{3}$ \\ ABSTRACT. The Holocene Dead Sea and the late Pleistocene Lake Lisan were characterized by varying radiocarbon res- \\ ervoir ages ranging between 6 and $2 \mathrm{ka}$ in the Dead Sea and between $2 \mathrm{ka}$ and zero in Lake Lisan. These changes reflect the \\ hydrological conditions in the drainage system as well as residence time of ${ }^{14} \mathrm{C}$ in the mixed surface layer of the lake and its \\ lower brine. Long-term isolation of the lower brine led to ${ }^{14} \mathrm{C}$ decay and an increase in the reservoir age. Yet, enhanced runoff \\ input with atmospheric ${ }^{14} \mathrm{C}$ brings the reservoir age down. The highest reservoir age of $6 \mathrm{ka}$ was recorded after the sharp fall \\ of the Dead Sea at $\sim 8.1 \mathrm{ka}$ cal BP. The lower reservoir age of zero was recorded between 36 and $32 \mathrm{ka}$ cal BP, when the Lake \\ Lisan mixed layer was frequently replenished by runoff.
}

\section{INTRODUCTION}

Radiocarbon dating of the Dead Sea shallow and deep water masses, as well as its carbonate sediments, depends on the evaluation of the "reservoir age" (RA) of the water, which requires an understanding of the fate of ${ }^{14} \mathrm{C}$ during the runoff evolution that is the main dissolved inorganic carbon (DIC) input into the lake. Waters flowing over carbonate terrains, like the Judean Mountains west of the Jordan-Arava Valley, or percolating through carbonate aquifers, may contain substantial amounts of "dead" carbon in their DIC. This DIC gets incorporated into the "new" precipitated carbonates, causing an apparent increase in the ${ }^{14} \mathrm{C}$ ages.

Analyses of fresh and saline waters from the Dead Sea drainage area show that runoff waters are characterized by a high percent of modern carbon values $(\sim 100 \mathrm{pMC})$, while springs that percolate throughout the Cretaceous carbonate aquifers are characterized by significantly lower values ( $\sim 50 \mathrm{pMC}$, cf. Talma et al. 1997). Most of the annual bicarbonate supply for aragonite precipitation in the Dead Sea-lacustrine system comes from freshwater, while the Dead Sea brine supplies calcium (Stein et al. 1997; Barkan et al. 2001). Therefore, aragonite layers deposited in the Dead Sea may contain various amounts of ${ }^{14} \mathrm{C}$ depending on the proportions of water types entering the lake and the nature of their relative mixing with Dead Sea brine (besides possible age effects). The combined effect of these mechanisms determines the reservoir age of the Dead Sea.

The Holocene Dead Sea is a remnant water body after the significantly larger, deeper, and relatively less saline Lake Lisan that existed in the Dead Sea basin during the Last Glacial period (Neev and Emery 1967; Begin et al. 1974; Katz et al. 1977; Stein 2001). The annual nature of sedimentation in the lake (Migowski et al. 2004) and the possibility to obtain both ${ }^{14} \mathrm{C}$ ages from the aragonite laminae and from associated organic debris opens a way to resolve secular changes in the ${ }^{14} \mathrm{C} \mathrm{RA}$ in the lake. In this paper, we summarize the available ${ }^{14} \mathrm{C}$ RA data from the late Pleistocene Lake Lisan (for the time interval of 36 to $17 \mathrm{ka} \mathrm{BP}$ ) and the Holocene Dead Sea (past $10 \mathrm{ka}$ ), and discuss their relation to the hydrological-limnological history of the lake system.

\footnotetext{
${ }^{1}$ Geological Survey of Israel 30 Malkhe Yisrael Street, Jerusalem 95501, Israel.

Corresponding author. Email: motis@vms.huji.ac.il.

${ }^{2}$ GeoForschungsZentrum Potsdam, Sec. 3.3 Climate Dynamics and Sediments, Telegrafenberg, D-14473 Potsdam, Germany.

${ }^{3}$ Institute of Earth Sciences, The Hebrew University of Jerusalem, Givat Ram, Jerusalem 91904, Israel.
} 


\section{LAKE LISAN AND THE DEAD SEA LIMNOLOGICAL SYSTEMS}

Lake Lisan existed between 70 and 14 ka BP (Kaufman 1971; Haase-Schramm et al. 2004). During the time of highest water level ( $>170$ meters below mean sea level [m bmsl]), the lake extended over about $300 \mathrm{~km}$ from the Sea of Galilee in the north to the Hazeva area in the south. The Lisan Formation, which was deposited within the lake and its surrounding fan deltas, consists mainly of chemical precipitates, aragonite and gypsum, and clastic material transported by floods. The aragonite appears in thin $(\sim 0.5-1 \mathrm{~mm}$ thick) laminae alternating with detrital laminae of similar or larger thickness. The aragonite precipitated most likely from the surface water and is preserved in its primary state due to the dry climate in the Dead Sea basin and the high $\mathrm{Mg} / \mathrm{Ca}$ ratio of interstitial soluble salts (remnants of the former porewater; Katz and Kolodny 1989; Stein et al. 1997).

The excellent preservation and high $\mathrm{U}$ concentrations ( $\sim 3 \mathrm{ppm})$ of Lisan aragonite make it useful for ${ }^{234}{ }^{2}-{ }^{230}$ Th dating (Kaufman 1971; Schramm et al. 2000; Haase-Schramm et al. 2004). The U-Th ages established by TIMS on aragonites from the Perazim Valley (PZ1) section lie in the range of $\sim 70$ to $14 \mathrm{ka}$ BP (Haase-Schramm et al. 2004).

The average rate of aragonite precipitation during the Lisan period was $1.5 \mathrm{~m}$ eq $\mathrm{HCO}_{3}$ per $\mathrm{cm}^{2} \mathrm{yr}^{-1}$, which is 4 to 5 times higher than the rate of the present Dead Sea (Barkan et al. 2001). Such a high precipitation rate required a substantial supply of bicarbonate to the lake, which was furnished by the incoming freshwater that most likely stratified the water column (Stein et al. 1997). The lower density surface layer reached aragonite saturation.

At $\sim 13 \mathrm{ka}$ cal BP, Lake Lisan receded rapidly, arriving to its minimum level of below $500 \mathrm{~m}$ bmsl (Stein 2002). The lake (now termed the "Dead Sea") recovered at the beginning of the Holocene, when it stabilized around the elevation of $400 \mathrm{~m}$ bmsl with a few fluctuations of up to $30 \mathrm{~m}$ (KenTor et al. 2002; Bookman et al. 2004; Migowski et al. 2004). The sedimentary lacustrine section of the Holocene Dead Sea resembles that of Lake Lisan, where sequences of aragonite and silty detritus alternate with thicker sandy and gypsum layers. During the past several hundred years, the Dead Sea has stabilized as a 2-layered meromictic lake, which was disrupted by the 1978 overturn (Stiller and Chung 1984).

\section{${ }^{14}$ C RESERVOIR AGES IN LAKE LISAN-DEAD SEA ARAGONITES}

The RAs in the late Pleistocene Lake Lisan and the Holocene Dead Sea are evaluated by subtracting the U-Th calendar age of Lisan aragonite or the ${ }^{14} \mathrm{C}$ age (ka BP) of organic debris (such as wood remains, leaves, twigs) from the measured ${ }^{14} \mathrm{C}$ age (ka BP) of the aragonite laminae in the same stratigraphic horizon (Table 1). Samples were collected in the Perazim Valley section (PZ1, described by Haase-Schramm et al. 2004), Massada section (beneath the archaeological site, see Bartov et al. 2002), and in the Ze'elim gully (Bookman et al. 2004), and were recovered from a sedimentary core drilled in Ein Gedi spa (Migowski et al. 2004). ${ }^{14} \mathrm{C}$ data are listed in Table 1 and are illustrated in Figure 1 against the level chronology of the lakes. During the Holocene, the RA displays temporal decrease from an elevated value of $6 \mathrm{ka}$ at $\sim 7.6 \mathrm{ka}$ cal BP (after the Dead Sea sharp fall at $8.1 \mathrm{ka}$ cal BP) to $2.2 \mathrm{ka}$ at present. One pair that was sampled below the high RA peak, at $9.1 \mathrm{ka}$ cal BP, yielded a lower RA of $3.3 \mathrm{ka}$. It appears that the brine carried an older ${ }^{14} \mathrm{C}$ memory from the earlier stages of the Holocene and the post-glacial period (when the lake level was at its minimum stand; Stein 2002). When the first aragonite deposited at $\sim 7.6 \mathrm{kacal} \mathrm{BP}$, the mixed layer accommodated a significant contribution of old carbon from the brine. 
Table 1 Lake levels and ${ }^{14} \mathrm{C}$ ages on aragonite and organic matter and U-Th ages data from Lake Lisan and the Holocene Dead Sea.

\begin{tabular}{|c|c|c|c|c|c|c|c|c|c|}
\hline $\begin{array}{l}\text { Sample } \\
\text { ID }\end{array}$ & Location & $\begin{array}{l}\text { Lake level } \\
(\mathrm{m} \mathrm{bmsl})^{\mathrm{a}}\end{array}$ & $\begin{array}{l}\text { Sample } \\
\text { type }\end{array}$ & $\begin{array}{l}\text { Measured } \\
{ }^{14} \mathrm{C} \text { age } \\
(\mathrm{ka} \mathrm{BP})\end{array}$ & \pm & $\begin{array}{l}\text { RA } \\
\text { (ka) }\end{array}$ & $\begin{array}{l}\text { Calibrated } \\
{ }^{14} \mathrm{C} \text { age } \\
\text { (cal ka BP) }\end{array}$ & $\begin{array}{l}\text { Calendar } \\
\text { U-Th age } \\
\text { (ka BP) }\end{array}$ & $\begin{array}{l}\text { Data } \\
\text { source }^{b}\end{array}$ \\
\hline \multicolumn{10}{|l|}{ Lake Lisan } \\
\hline PZ1-2290 & \multirow[t]{2}{*}{ Perazim } & \multirow[t]{2}{*}{280} & aragonite & $32.8^{c}$ & 1.1 & \multirow[t]{2}{*}{$\sim 0^{\mathrm{a}}$} & - & 37 & \multirow[t]{2}{*}{1} \\
\hline PZ1 2236-W & & & wood & 35.9 & 2.7 & & - & - & \\
\hline PZ1 2450 & \multirow[t]{2}{*}{ Perazim } & \multirow[t]{2}{*}{280} & aragonite & 30.6 & 0.6 & \multirow[t]{2}{*}{$\sim 0^{\mathrm{b}}$} & - & 34 & \multirow[t]{2}{*}{1} \\
\hline PZ1 2450-L & & & leaf & $32.6^{\mathrm{d}}$ & 1.1 & & - & - & \\
\hline \multirow[t]{2}{*}{ PZ-1 2558} & \multirow[t]{2}{*}{ Perazim } & \multirow[t]{2}{*}{280} & aragonite & 30.5 & 0.3 & \multirow[t]{2}{*}{0} & - & 33 & \multirow[t]{2}{*}{2} \\
\hline & & & wood & 30.5 & 0.3 & & - & - & \\
\hline \multirow[t]{2}{*}{ MS-410 } & \multirow[t]{2}{*}{ Massada } & \multirow[t]{2}{*}{180} & aragonite & 24.0 & 0.2 & \multirow[t]{2}{*}{1.5} & - & 24 & \multirow[t]{2}{*}{3} \\
\hline & & & wood & 22.5 & 0.2 & & - & - & \\
\hline \multirow[t]{2}{*}{ MS-405 } & \multirow[t]{2}{*}{ Massada } & \multirow[t]{2}{*}{180} & aragonite & 24.0 & 0.2 & \multirow[t]{2}{*}{1.7} & - & 24 & \multirow[t]{2}{*}{3} \\
\hline & & & wood & 22.3 & 0.2 & & - & - & \\
\hline M-2375 & \multirow[t]{2}{*}{ Massada } & 180 & aragonite & 22.7 & 0.2 & 2.0 & - & 24 & 1 \\
\hline M-2374 W & & & wood & 20.7 & 0.2 & & - & - & \\
\hline ID 455 & Perazim & 200 & aragonite & 22.0 & 0.1 & 1.3 & - & 23 & 2 \\
\hline & & & wood & 20.7 & 0.1 & & - & - & \\
\hline MS-179 & Massada & 200 & aragonite & 19.5 & 0.1 & 1.4 & - & 21 & 3 \\
\hline & & & wood & 18.2 & 0.1 & & - & - & \\
\hline MS-218 & Massada & 200 & aragonite & 19.0 & 0.1 & 2.0 & - & 19 & 3 \\
\hline & & & wood & 17.0 & 0.1 & & - & - & \\
\hline PZ1-3649 & Perazim & 200 & aragonite & 14.5 & 0.1 & 1.6 & - & 17 & 1 \\
\hline & & & debris & 12.9 & 0.2 & & - & - & \\
\hline Dead Sea & & & & & & & & & \\
\hline & $\mathrm{EG}^{\mathrm{e}}$ core & 400 & aragonite & 2.38 & 0.07 & 2.2 & 0.1 & - & 4 \\
\hline & & & twigs & 0.16 & 0.03 & & & - & \\
\hline & EG core & 400 & aragonite & 2.97 & 0.07 & 2.2 & 0.2 & - & 4 \\
\hline & & & twigs & 0.80 & 0.03 & & & - & \\
\hline & EG core & 400 & aragonite & 3.86 & 0.07 & 2.3 & 1.1 & - & 4 \\
\hline & & & plant fiber & 1.56 & 0.03 & & & - & \\
\hline & EG core & 370 & aragonite & 6.09 & 0.04 & 2.4 & 4.1 & - & 4 \\
\hline & & & twigs & 3.68 & 0.03 & & & - & \\
\hline & EG core & 400 & aragonite & 7.92 & 0.07 & 2.6 & 6.2 & - & 4 \\
\hline & & & twigs & 5.28 & 0.04 & & & - & \\
\hline & EG core & 400 & aragonite & 9.85 & 0.07 & 3.4 & 7.4 & - & 4 \\
\hline & & & twigs & 6.46 & 0.07 & & & - & \\
\hline & EG core & $<450$ & aragonite & 12.7 & 1.2 & 6.0 & 7.7 & - & 4 \\
\hline & & & twigs & 6.73 & 0.04 & & & - & \\
\hline & EG core & 400 & aragonite & 11.5 & 1.2 & 3.3 & 9.1 & - & 4 \\
\hline & & & twigs & 8.20 & 0.04 & & & - & \\
\hline
\end{tabular}

${ }^{\mathrm{a}} \mathrm{m}$ bmsl= meters below mean sea level.

${ }^{b}$ Data sources: 1=Haase-Schramm et al. 2004; 2=van der Borg et al. 2004; 3=Prasad et al., forthcoming; 4=present study.

${ }^{\mathrm{c}}$ The ${ }^{14} \mathrm{C}$ age was obtained on aragonite from a stratigraphically younger layer; thus, considering short transport time of the wood and the large error on sample PZ1-2236-W, the estimated RA at 2236 is about zero.

${ }^{\mathrm{d}}$ The leaf is slightly older than the aragonite; therefore, the reservoir age was estimated to be about zero.

eEG denotes Ein-Gedi. 


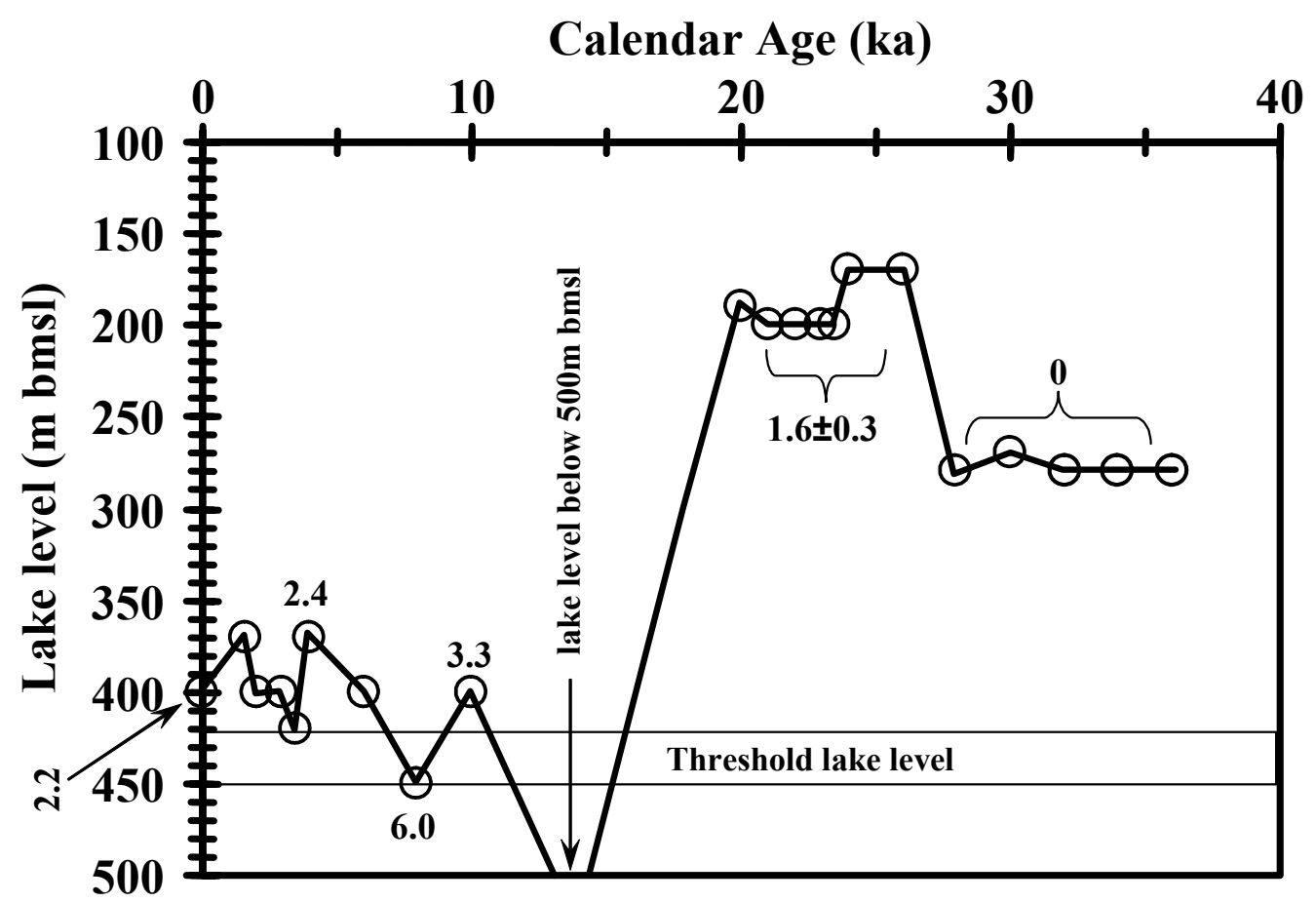

Figure 1 Reservoir ages (RA in ka units) during various water levels of the Last Glacial Lake Lisan and the Holocene Dead Sea. Lake-level data are from Bartov et al. 2002, 2003; Bookman et al. 2004; Migowski et al. 2004.

During the Lisan period (considering the time intervals where aragonite-organic debris pairs are available), the RAs cluster around 2 values: (1) about zero between 36 and $32 \mathrm{ka} \mathrm{BP}$; and (2) $1.6 \pm 0.3 \mathrm{ka}$, between 24 and $20 \mathrm{ka}$ BP. Figure 2 displays the RAs at various lake-level conditions. It appears that the RA is related in a complicated way to the lake level, which is the most prominent hydrological indicator in the lake system. While the early Holocene Dead Sea shows RAs that are significantly higher than Lake Lisan, the mid-late Holocene Dead Sea (past 4000 yr) RAs are not much different from the high-stand Lake Lisan ( $2.3 \pm 0.1 \mathrm{ka}$ compared with $1.6 \pm 0.3 \mathrm{ka}$, respectively). More surprising is the zero RA recorded by Lake Lisan at its "typical" elevation of $\sim 280 \mathrm{~m}$ bmsl. These observations indicate that the RA is not a simple function of freshwater bicarbonate supply to the lake, and other factors such as ${ }^{14} \mathrm{C}$ decay in the water body are involved.

\section{DISCUSSION}

\section{Residence Time of ${ }^{14} \mathrm{C}$ in the Modern Dead Sea}

The dynamics of the carbonate system of the Dead Sea were investigated after unusually high rainfall and enhanced runoff in the winter of 1991/92, which came after years of continuous retreat mainly due to anthropogenic interference (Barkan et al. 2001). The intense flooding formed a shallow pycnocline that divided the water column into 2 dissolved inorganic carbon (DIC) reservoirs: the shallow (about $20 \mathrm{~m}$ deep) surface mixed layer DIC reservoir opened to the atmosphere, and a large deep water DIC reservoir isolated from the atmosphere. This salinity stratification of the Dead Sea lasted for more than $2 \mathrm{yr}$. The average DIC value in the Dead Sea is $850 \mu \mathrm{mol} \cdot \mathrm{kg}^{-1}$, which is much lower than in the freshwater runoff. The measured $P_{\mathrm{CO}_{2} \text { (liquid) }}$ was very high, approximately $2000 \mu \mathrm{atm}$ (compared to the atmospheric value of $355 \mu \mathrm{atm}$ ) at all depths. This high $P_{\mathrm{CO}_{2}(\text { liquid })}$ 


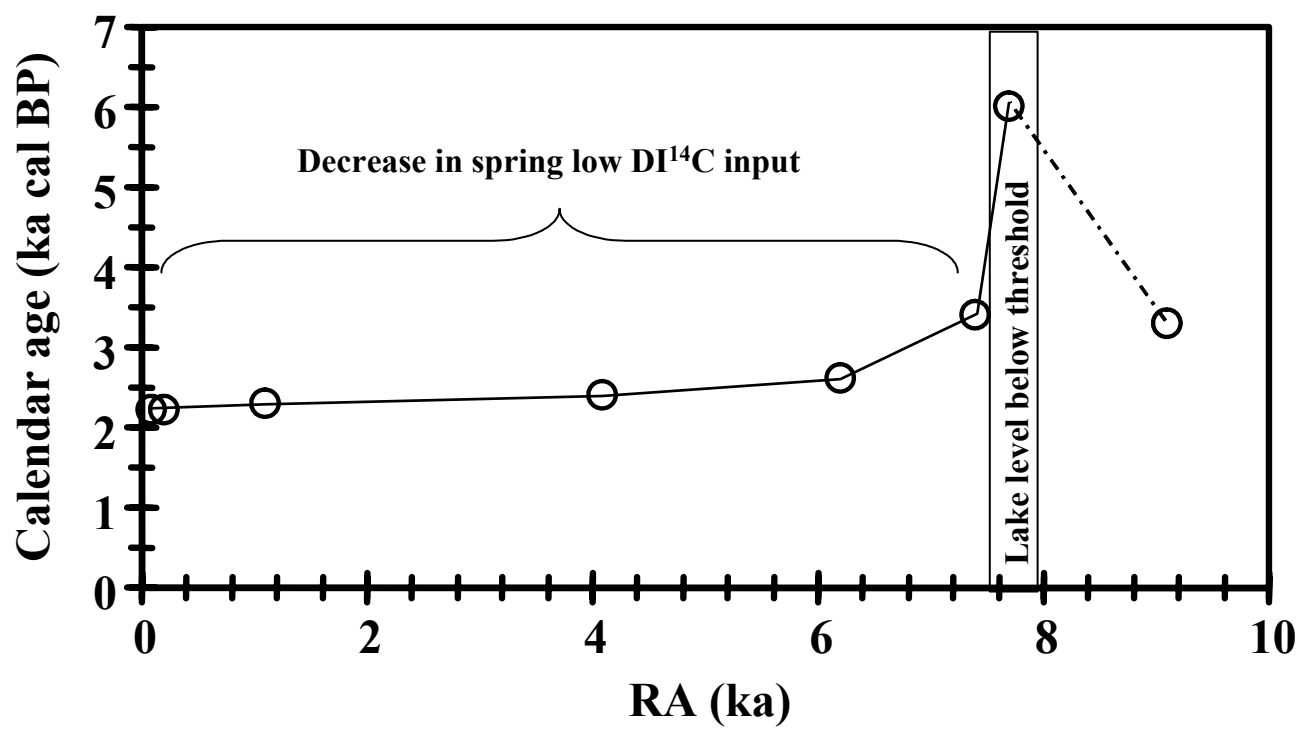

Figure 2 Reservoir age (RA in ka) versus calibrated ${ }^{14} \mathrm{C}$ age in the Holocene core drilled at Ein Gedi shore. Note the fast decrease from the reservoir age peak at $7.6 \mathrm{ka}$ cal BP, and the following moderate decrease in the reservoir age, reflecting the decrease in DIC supply of springs with low DI ${ }^{14} \mathrm{C}$ (groundwater DIC source with low ${ }^{14} \mathrm{C}$ content) and the continuous replenishment by runoff water with high $\mathrm{DI}^{14} \mathrm{C}$ content (atmospheric ${ }^{14} \mathrm{C}$ ).

represents a DIC excess (above equilibrium with atmospheric $\mathrm{CO}_{2}$ ) of about $300 \mu \mathrm{mol} \cdot \mathrm{kg}^{-1}$, which is equivalent to $40 \%$ of the DIC. The carbon fluxes in the Dead Sea as estimated for the years 1992 to 1994 were (1) $\mathrm{HCO}_{3}^{-}$influx with floods of $\left.2.1 \mathrm{~mol} \cdot \mathrm{m}^{-2} \cdot \mathrm{a}^{-1}\right)$; (2) $\mathrm{CaCO}_{3}$ precipitation of $1.4 \mathrm{~mol} \cdot \mathrm{m}^{-2} \cdot \mathrm{a}^{-1}$ that occurred in the mixed layer; and (3) a large $\mathrm{CO}_{2}$ escape to the atmosphere of $4 \mathrm{~mol} \cdot \mathrm{m}^{-2} \cdot \mathrm{a}^{-1}$ driven by the high $P_{\mathrm{CO}_{2} \text { (liquid) }}$.

The overall DIC balance for the mixed layer suggested a net DIC loss of $3.3 \mathrm{~mol} \cdot \mathrm{m}^{-2} \cdot \mathrm{a}^{-1}$, which can potentially deplete the mixed layer DIC within $10 \mathrm{yr}$ and the whole water column within about 100 yr. Earlier DIC data (Neev and Emery 1967; Luz et al. 1997) suggested that these conditions of $P_{\left.\mathrm{CO}_{2} \text { (liquid) }\right)} \gg P_{\mathrm{CO}_{2}(\mathrm{~atm})}$ also prevailed in the deep-water column during the several centuries of continuous meromictic stages which prevailed before the 1978 overturn (Stiller and Chung 1984; Barkan et al. 2001). The existence of such high $P_{\mathrm{CO}_{2}(\text { (liquid) })}$ over a time period that is longer than the calculated residence time of DIC in the deep-water mass of the Dead Sea suggests that the deep DIC reservoir (the main DIC reservoir of the Dead Sea) remained during the whole meromictic stage. Thus, the ${ }^{14} \mathrm{C}$ content of the large deep-water reservoir was several hundred years old when ventilated during the 1978 overturn, increasing the RA of the newly formed mixed layer.

When the lake is stratified during meromictic stages, the ${ }^{14} \mathrm{C}$ content of the surface mixed layer (from which the authigenic carbonate precipitates) may change rapidly. For example, in the modern Dead Sea, the residence time of carbon in the mixed layer is about $8 \mathrm{yr}$, implying that the RA may approach zero after about $20 \mathrm{yr}$ of continuous stratification. On the other hand, during the holomictic stage (when the lake mixes entirely at least during one period a year), the deep-water column serves as a buffer for abrupt changes in the ${ }^{14} \mathrm{C}$ content of surface water and, hence, the RA of the lake. 


\section{Residence Time of ${ }^{14} \mathrm{C}$ in the Old Lakes}

The high peak of the RA at $7.6 \mathrm{ka}$ cal BP, when the Dead Sea was at one of its lowest stands $\sim 417 \mathrm{~m}$ bmsl (Migowski et al. 2004), and the secular decrease in RA that followed this RA peak are key observations for understanding the behavior of ${ }^{14} \mathrm{C}$ in the old lakes. We suggest that the extremely high RA ( $6 \mathrm{ka}$ ) at $7.6 \mathrm{ka}$ cal BP indicates that i) springs (mainly saline springs having very low ${ }^{14} \mathrm{C}$ ) were the main freshwater input into the Dead Sea during its low-stand, while runoff input (with high ${ }^{14} \mathrm{C}$ ) was virtually shut down; and ii) the Dead Sea remnant brine that filled the deep basin after the strong retreat at $8.1 \mathrm{ka}$ cal BP could have been isolated for several thousand years (Figure 1), causing additional decrease in ${ }^{14} \mathrm{C}$ content due to decay. When the hydrological system recovered and runoff re-entered the lake, the RA began its continuous decrease towards the present value of 2.2 $\mathrm{ka}$ (Figure 2). This decrease is the result of continuous mixing of freshwater with atmospheric ${ }^{14} \mathrm{C}$ with the Dead Sea brine. At $~ 3.3 \mathrm{ka}$ cal BP, the Dead Sea level dropped again (Bookman et al. 2004; Migowski et al. 2004). Yet, we see no increase in the RA during the time interval of 4.1 to $1.1 \mathrm{ka} \mathrm{cal}$ BP. This may indicate that the threshold lake level is between 420 and $450 \mathrm{~m}$ bmsl (Figure 1): when the lake level is above this threshold, runoff is the main DIC supply of the lake; and when the lake level is below this threshold, springs (fresh and saline groundwater sources) are the main DIC source of the lake. Apparently, the level decrease at $\sim 3.3 \mathrm{ka}$ cal BP was not accompanied by long brine isolation that could support an additional increase in RA due to ${ }^{14} \mathrm{C}$ decay.

During the Lisan time (70 to $14 \mathrm{ka} \mathrm{BP}$ ), the RA was significantly lower than the Holocene value (Figure 1 and Table 1), suggesting that the main DIC input was runoff and the brine was never isolated for long periods of time from the mixed layer. The lake level during that period was always above the threshold level (Figure 1). The data shows that Lake Lisan had a zero RA value during the time interval that ended just before the lake reached its highest stand (Figure 1). This zero RA value was measured for the time interval that ends at the dating limit of the ${ }^{14} \mathrm{C}$ method. The lake level at this period was stabilized at $280 \mathrm{~m}$ bmsl (Bartov et al. 2002), some $120 \mathrm{~m}$ above the present-day level of the Dead Sea. It is possible that the RA of Lake Lisan was zero before its highest stand due to fast replenishment of the surface water with runoff DIC (with high ${ }^{14} \mathrm{C}$ content). The increase in lake area during the high-stand may have added "new" low ${ }^{14} \mathrm{C}$ DIC sources. It is well documented that during the period of maximum stand (26-24 ka cal BP), Lake Lisan converged with the northern Sea of Galilee (Hazan et al., forthcoming). The high-stand was characterized by a stable layered configuration that persisted for several thousand years during which ${ }^{14} \mathrm{C}$ content of the lower brine decreased. Thus, some contribution to RA in the mixed layer could come from the brine. In addition, the aquifers formed during the lake's highest stand may have supplied spring waters with low ${ }^{14} \mathrm{C}$ content, which kept a low RA during the time after the highest stand.

\section{CONCLUSIONS}

The Holocene Dead Sea and late Pleistocene Lake Lisan were characterized by varying reservoir ages. In the Holocene Dead Sea, the RA ranges between 2.2 and $6 \mathrm{ka}$; and in the Lisan, they range from zero to $2.0 \mathrm{ka}$. These variations reflect the proportions of DIC supplied by freshwater from runoff and springs and periods of brine isolation and mixing with the surface (aragonite precipitating) layer.

The data of the last $36 \mathrm{ka}$ of the lake suggest that the Lisan time was characterized by 2 modes of limnological operation and ${ }^{14} \mathrm{C}$ content: (1) relatively low lake levels, when fast replenishment of the mixed layer occurred, were characterized by zero RA; (2) long high-stand periods, when the lake 
developed a stable 2-layer configuration that allowed ${ }^{14} \mathrm{C}$ decay in the lower (brine) layer, and particularly, when areas with enhanced spring activity contributed old carbon to the lakes.

The Holocene low-stand showed the highest RA (6 ka) at lake level lower than about $440 \mathrm{~m}$, indicating that saline springs became an important low ${ }^{14} \mathrm{C}$ DIC source for the lake.

\section{ACKNOWLEDGEMENTS}

We thank Nicolas Waldmann and Miryam Freed on help in fieldwork, and separation of aragonite laminae. This study was supported by ISF grant to MS and BL and by GIF grant to MS.

\section{REFERENCES}

Barkan E, Luz B, Lazar B. 2001. Dynamics of the carbon dioxide system in the Dead Sea. Geochimica et Cosmochimica Acta 65:355-68.

Bartov Y, Stein M, Enzel Y, Agnon A, Reches Z. 2002. Lake-levels and sequence stratigraphy of Lake Lisan, the Late Pleistocene precursor of the Dead Sea. Quaternary Research 57:9-21.

Bartov Y, Goldstein SL, Stein M, Enzel Y. 2003. Catastrophic arid episodes in the Eastern Mediterranean linked with the North Atlantic Heinrich events. Geology 31:439-42.

Begin ZB, Ehrlich A, Nathan Y. 1974. Lake Lisan, the Pleistocene precursor of the Dead Sea. Bulletin 63:130

Bookman R, Enzel Y, Agnon A, Stein M. 2004. Late Holocene lake levels of the Dead Sea. Geological Society of America Bulletin 116.

Haase-Schramm A, Goldstein SL, Stein M. 2004. U-Th dating of Lake Lisan aragonite (late Pleistocene Dead Sea) and implications for glacial East Mediterranean climate change. Geochimica and Cosmochimica Acta 68:985-1005.

Hazan N, Stein M, Agnon A, Marco S, Nadel D, Schwab M, Negendank J, Neev D. Forthcoming. The late Pleistocene-Holocene history of the Sea of Galilee (Lake Kinneret). Quaternary Research.

Luz B, Stiller M, Talma S. 1997. Carbon dynamics in the Dead Sea. In: Niemi TM, Ben-Avraham Z, Gat JR, editors. The Dead Sea: The Lake and Its Setting. Oxford Monographs on Geology and Geophysics, $\mathrm{Nr}$ 36, Oxford

Katz A, Kolodny N. 1989. Hypersaline brine diagenesis and evolution in the Dead Sea-Lake Lisan system (Israel). Geochimica et Cosmochimica Acta 53:59-67.

Katz A, Kolodny Y, Nissenbaum A. 1977. The geochemical evolution of the Pleistocene Lake Lisan-Dead Sea system. Geochimica et Cosmochimica Acta 41:1609 26.

Kaufman A. 1971. U-series dating of Dead Sea basin carbonates. Geochimica et Cosmochimica Acta 35:126981.

Ken-Tor R, Stein M, Enzel Y, Agnon A, Marco S, Negendank J. 2002. Precision of calibrated radiocarbon ages of earthquakes in the Dead Sea basin. Radiocarbon 43(3):1371-82.

Migowski C, Agnon A, Bookman R, Negendank J, Stein M. 2004. Recurrence pattern of Holocene earthquakes along the Dead Sea transform revealed by varve-counting and radiocarbon dating of lacustrine sediments. Earth and Planetary Science Letters 222:301-14.

Neev D, Emery KO. 1967. The Dead Sea depositional processes and environments of evaporites. Israel Geological Survey Bulletin 41.147 p.

Prasad S, Vos H, Waldmann N, Goldstein SL, Stein M. Forthcoming. Evidence from Lake Lisan of solar influence on decadal to centennial scale climate variability during MIS 2. Geology.

Schramm A, Stein M, Goldstein SL. 2000. Calibration of the ${ }^{14} \mathrm{C}$ timescale to $>40 \mathrm{ka}$ by ${ }^{234} \mathrm{U}-{ }^{230} \mathrm{Th}$ dating of Lake Lisan sediments (Last Glacial Dead Sea). Earth and Planetary Science Letters 175:27-40.

Stein M. 2001. The sedimentary and geochemical record of Neogene-Quaternary water bodies in the Dead Sea basin-inferences for the regional paleoclimatic history. Journal of Paleolimnology 26:271-82.

Stein M. 2002. The fall and rise of the Dead Sea during the post-glacial and the Younger Dryas event. Geochimica Cosmochimica Acta 12th Annual Goldschmidt Conference. Davos, A738.

Stein M, Starinsky A, Goldstein SL, Katz A, Machlus M, Schramm A. 1997. Strontium isotopic, chemical, and sedimentological evidence for the evolution of Lake Lisan and the Dead Sea. Geochimica et Cosmochimica Acta 61:3975-92.

Stiller M, Chung YC. 1984. Radium in the Dead Sea: a possible tracer for the duration of meromixis. Limnology and Oceanography 29:574-86.

Talma AS, Vogel JC, Stiller M. 1997. The radiocarbon content of the Dead Sea. In: Niemi TL, Ben-Avraham Z, Gat J, editors. The Dead Sea: The Lake and Its Setting. Oxford: Oxford University Press. p 171-83.

van der Borg K, Stein M, de Jong AFM, Waldmann N, Goldstein SL. 2004. Atmospheric ${ }^{14} \mathrm{C}$ at 33 ka close to the AD 1950 level as observed in the high-resolution radiocarbon record from $U$-Th dated sediment of Lake Lisan. Radiocarbon, these proceedings. 